\title{
ANALYTICAL COMPARISON BETWEEN INFORMAL-RANDOM- HOUSING AND GRAVEYARDS HOUSING -A CASE STUDY- HOUSING INSIDE THE NORTHERN GABANA AREA, IN CAIRO CITY
}

\author{
Mohammed Mohamed Abdulhameed
}

A teacher at the Department of Architecture, College of Engineering - Al-Azhar University

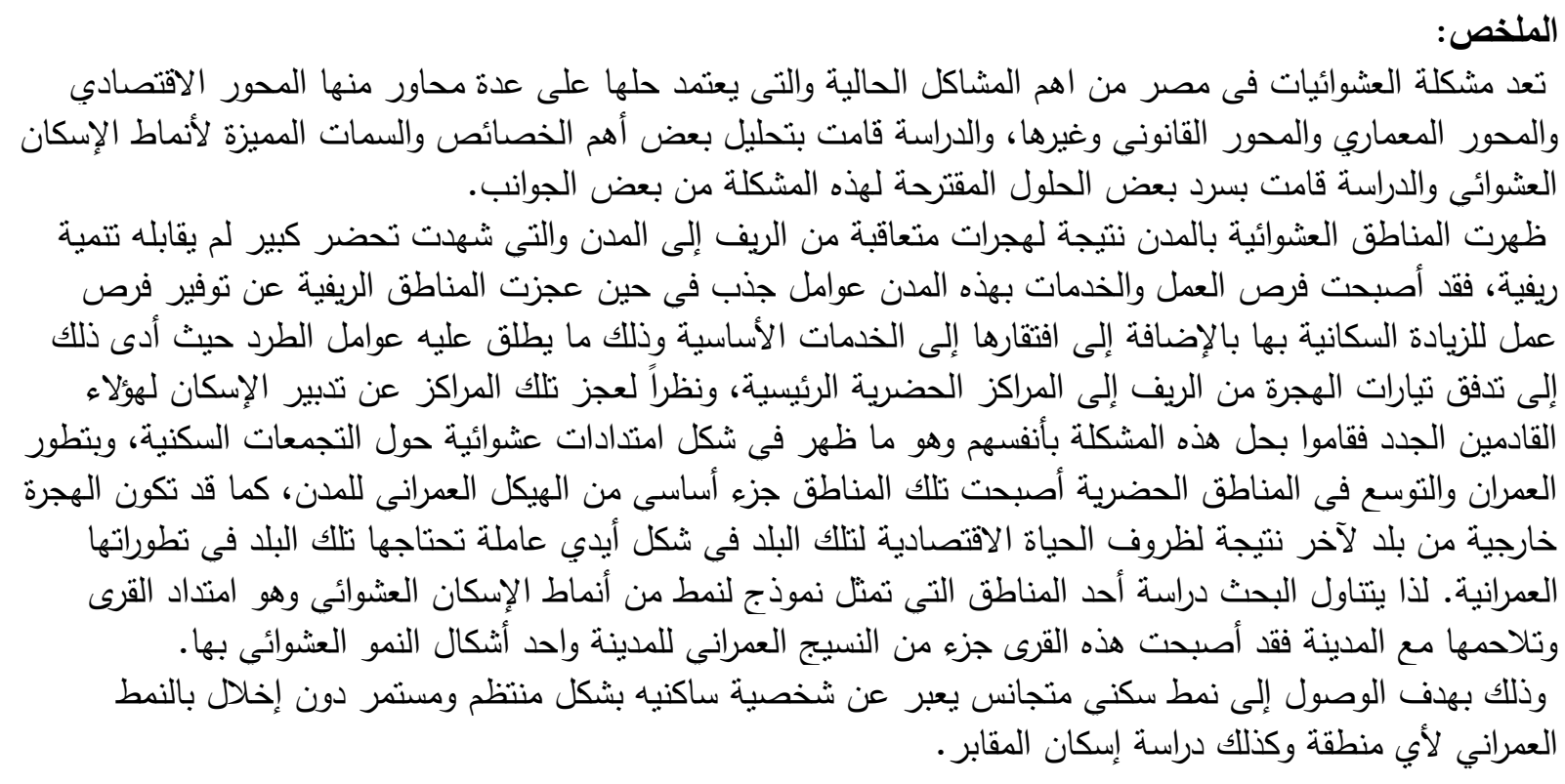

\begin{abstract}
The informal residential areas have emerged in cities as a result of successive migrations from the countryside to cities, which have witnessed a large urbanization that was not matched by rural development. Employment opportunities and services in these cities became attracting factors, while rural areas were unable to provide job opportunities due to the population growth and lack of basic services which is called expulsion factors, this has led to the flow of migratory flows from rural areas to main urban centers. Because of the inability of these centers to supply housing for such newcomers, they have settled this problem themselves, which has emerged in the form of informal-random -extensions around residential communities, urbanization and expansion in urban areas. These areas have become an essential part of the urban structure of cities. Migration may be external to one country due to the economic life of that country, in the form of labor needed by that country in its urban development. So, the study deals with studying one of the areas that represents the model of a pattern of informal-random- housing, which is an extension of villages and their cohesion with the city, where these villages have become part of the urban fabric of the city as well as one of the forms of its informa 1 -random-growth
\end{abstract}




\section{INTRODUCTION}

Random growth for Residential areas has been considered a phenomenon where the majority of developing countries AR suffering from housing problem, it cannot be separated fom economic and social conditions for such communities; it is a direct expression about these conditions. Therefore, treating it as a problem ought to be through a comprehensive look which is being aware of the extent of entanglement where such a relation occurs.

Informal growth is a general phenomenon in the main urban centers inside the cities of developing countries, the availability of job opportunity in such centers has been considered among the most attracting factors for such areas, whereas rural areas are unable to offer job opportunities to meet the population increase, in addition to the lack of basic services which have led to the flow of migration from rural areas to urban centers that are unable to offer sufficient housing units for new arrivals, also they are unable to offer required housing units that meet the natural increase of the population of such areas, so those work on solving this problem themselves, consequently they appear in the form of informal extensions surrounding residential areas and inside them.

Informal -random-housing represents more than hay rate of the population size in Egypt, it is regarded as communities that have been emerged during the government's absence and under the absence of inforsement laws, there is no strict measures, they are formed for purpose of shelter need, and due to the lack of supply, and an increased demand for housing units that suit those who have a low income.

\section{Key Words: (Informal -Random-Housing-Graveyard Housing-Characteristics Of Informal Housing-Housing Patterns-Evaluation Of Informal Random Housing).}

First: Theoretical study:

It includes a set of analysis concerning the research problem, patterns of informal housing and various graveyard housing.

1-1 Definition of informal -random-housing and graveyards housing:

1-1-1 Informal -random-housing : It is defined as housing communities emerged in the absence of planning, a form of law breach, a violation against agricultural lands and State's properties. Such places are deprived of the minimum limit of all types of basic facilities, such as water, electricity, roads and sanitation, they have lacked any security health, education and transport services, it is considered a barrier for an ambulance or a firefighting vehicle to pass across their narrow uneven roads.

Among other definitions for informal-random- areas: they are unplanned housing complex, they represent a violation against a state's property or properties of others, they have been built without a license and lacking facilities and services, they have lacked such services completely. They are characterized by a low income for the majority of inhabitants who have usually practiced marginal works, it is a problem related first to the urban and not the rural areas.

\section{1-2 Graveyards Housing}

Features of poor informal housing have been applied for graveyard housing, such kind of housing is based in overlapped housing areas, in graveyards places, these which have been emerged due to a rapid urbanization, where housing has become nearer to tombs areas and they have overlapped. 


\begin{tabular}{|l|l|l|}
\hline \multicolumn{1}{|c|}{ A comparison } & \multicolumn{1}{|c|}{ Informal -random-housing } & \multicolumn{1}{c|}{ Graveyards housing } \\
\hline Income level & $\begin{array}{l}\text { The income level of population is very } \\
\text { low }\end{array}$ & $\begin{array}{l}\text { The income level is almost non- } \\
\text { existent }\end{array}$ \\
\hline Conditions of facilities and services & Degraded services and facilities & $\begin{array}{l}\text { facilities and services are totally } \\
\text { lacked }\end{array}$ \\
\hline $\begin{array}{l}\text { The percentage to the population in } \\
\text { Egypt }\end{array}$ & $\begin{array}{l}20 \% \text { of population of Egypt } 4 \text { in } \\
\text { Greater Cairo }\end{array}$ & $\begin{array}{l}\text { The recent statistics issued by the } \\
\text { Central Accounting Agency in 2008 } \\
\text { shows } \\
\text { inhabitants there is 1.5 million }\end{array}$ \\
\hline Examples in Greater Cairo & $\begin{array}{l}\text { Mansheyet Nassir - Duwaiqa - Azbet } \\
\text { Al-Haggana }\end{array}$ & $\begin{array}{l}\text { The tombs of the Basateen, the Tonsi, } \\
\text { Imam Shafi'i, Bab al-Wazir, al- } \\
\text { Ghafir, the Mujahideen, the Imam al- } \\
\text { Liithi, cemeteries of Ain Shams, Nasr } \\
\text { City, }\end{array}$ \\
\hline
\end{tabular}

A comparison between informal housing and graveyard housing in Greater Cairo

\section{1-3: Types of informal-random-housing and graveyards housing}

\section{1-3-1 Informal-random-housing}

1. 3.2 Types of informal-random- housing spread in the local community

\section{A. Informal -random-housing:}

It is a residence that has been built inside city-village administrative boundaries without obtaining pre licenses from concerned local authorities, but it has been implemented randomly without care to the area division, such a housing is almost deprived of basic facilities and public services.

\section{B. Deformed housing: shacks and cottages}

It is a kind of housing built by unstable materials or semi stable without considerations to environmental and health conditions as well as the absence of services(drinking watersanitation-electricity), they appear obviously across railways and waterways.

\section{Marginal or metaphorical housing:}

It means places that have been prepared originally for non residence, but occupied by inhabitants such as archeological sites, agencies, groceries, garages, under stairs, vacant sites inside buildings.

\section{Housing of a separated room:}

It is a family housing in one room of a narrow area, depraved building without separated facilities, other families share a toilet, such a room is located either on roofs or in house yards, inside this room, all family living activities take place like sleeping, setting, studying, cooking and storing, ... etc.

\section{E. Boats housing}

It is housing in small boats on the Nile or its branches where this phenomenon is spread among those who work in fishing and where their living, sleeping and residence are on boats.

F. Shelter housing: tents that are set up temporarily for those whose houses were damaged, they live their without any kind of facilities or basic services for life.

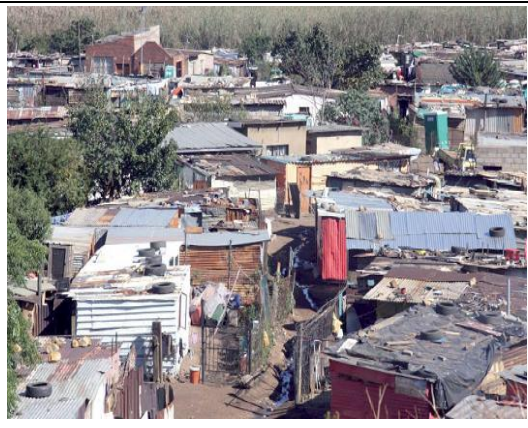

A Photo of houses built of shacks and tins

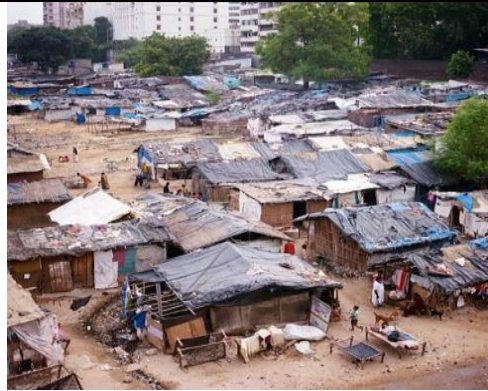

A Photo of the Dwaiqa residential areas where they lack all aspects of human life 


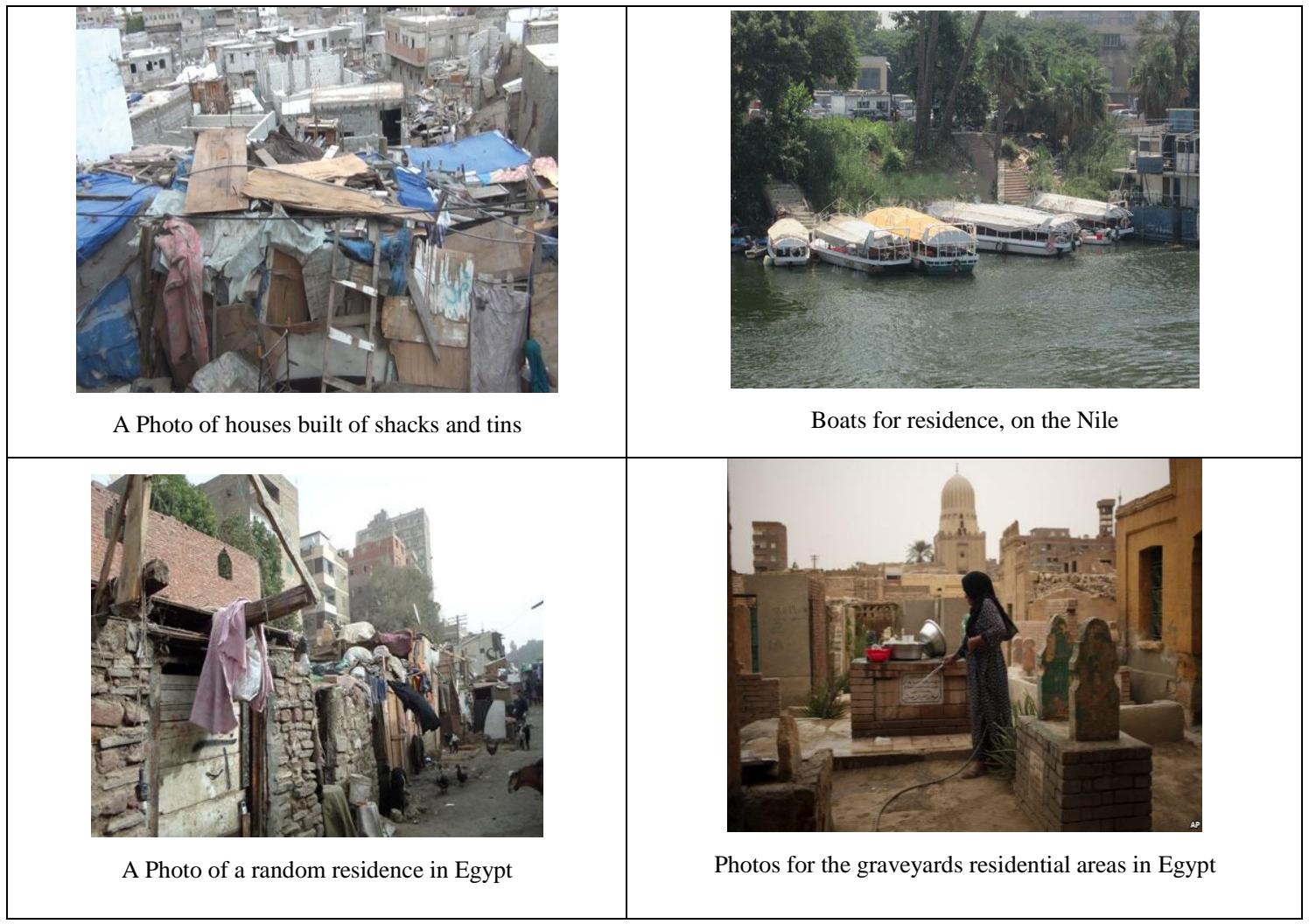

\section{G. Garbage collectors' Housing}

Garbage collectors chose some places so as to stay next to what they collect from rubbish as well as nearby the area, Landfills are bad and areas are deprived of clean water, sanitation and lighting, and the residential proximity of some of these areas was observed. There are also some of the rooms of sheet and wooden posts, water is usually drawn from the surrounding areas, and the families members are all seen around the trash container, which is loaded into a yard, which can be sorted and collected separately and sometimes they are shared by animals while searching for their food.

\section{1-3-3 The graveyard housing in the local community, the types of graveyards in Egypt} are summarized in the following:

A. The residential areas overlap with graveyards. These areas were created as a result of the growth of the large city in a relatively short period. The residential neighborhoods were moved towards cemeteries and around. The graveyards also moved towards the residential neighborhoods until they converged and were no longer separated, such as Qadiriyah and Arab Quraish in the north Shafei area.

B. The population islands within the cemeteries: This refers to the communities that were established within the areas of the cemeteries. These islands were established on the spaces within, such as the area of Imam al-Shafei around his mosque.
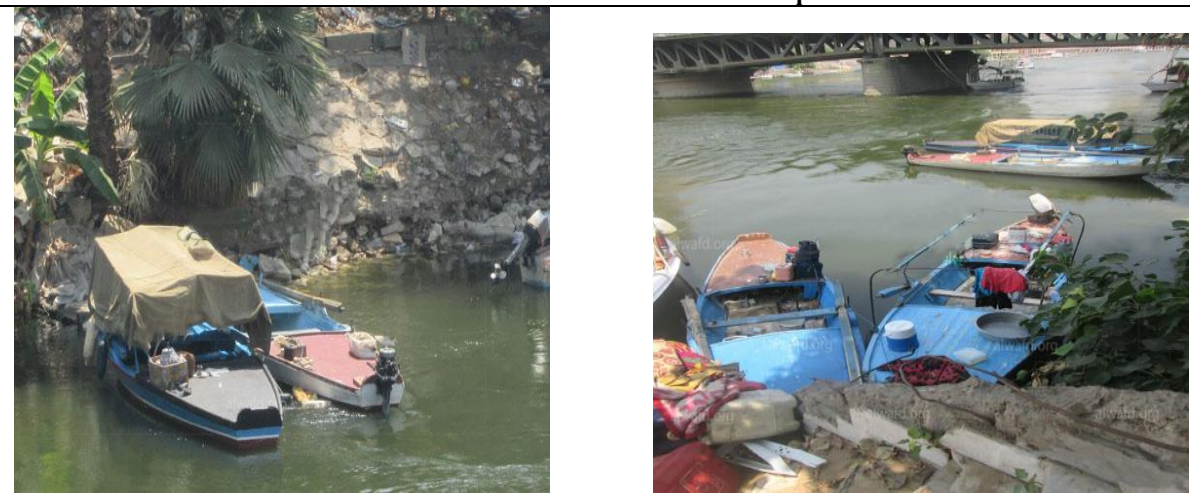

Boats resides on the Nile 
c. The inhabitants of the graveyards: There are approximately within $25 \mathrm{~km}$ thousand squares $\mathrm{Km}$. in the area of the graveyard in a pattern that allows the use of housing without making important changes, and the arena, next to the graves, the living rooms and services, allowing the establishment of sustainable neighborhoods.

\section{2-1Reasons for the emergence of random housing:}

A. The rising and the growth of the informal random housing is primarily due to the steady increase in population in Egypt: the increase is not matched by an increase in housing units, which are either built by the state or built by the private sector, moving On the land of Dallah or on the agricultural and desert lands or increase the number of floors beyond the allowed limits resulted in the emergence and spread of informal settlements in Egypt in this form, which is declined and backward.

B. Internal migration from rural to urban areas: One of the main reasons for the spread of informal -random-housing in Egypt is the migration of the population from the expelling provinces of the population such as (Menoufia - Gharbia - Beheira - Upper governorates) to the provinces with population attractions such as Cairo - Giza Qalioubia Alexandria) a matter that has led to the establishment of random gatherings on the outskirts of cities in these governorates and the increase of informal random growth.

C-The establishment of major industrial projects: The interest in large industries, especially the heavy industries and emerging industries in Helwan (south of Cairo) and Shubra Al-Khaima (north of Cairo) led to increased population concentration with increasing urban growth in these two regions.

D-Rising prices of land within cities. The rise of prices for land within cities, as well as the rise in the prices of building materials, have led to a rise in the cost of housing. Consequently, tends to establish informal urban communities outside the cities, mostly on agricultural lands around the outskirts of cities.

E-The government reduced the rental value of housing more than once, especially during the sixties, gradually withdrawing from the construction of housing with the aim of leasing to the reluctance of most people to build housing and the direction of the private sector, as well as the state to build housing for the purpose of ownership - not leasing which affected the number of housing units offered For rent in the market. This resulted in low-income people to build their own homes in stages, on the land of the state, and agricultural lands. This helped to spread the spread of random settlements in the outskirts of major cities, especially in the governorates of Cairo, Giza and Alexandria.

F-The lack of implementation of the laws of urban planning, construction, organization, division and land, in addition to the failure to implement the law of protection and agricultural land with all its accuracy, with harsh construction requirements and intensity, all of which led to the growth and growth of informal settlements in addition to the lack of adequate possibilities for regulatory authorities on the construction process to continue its oversight role.

G-Lack of interest in regional development: The lack of attention to regional development, which aims to redistribute the population out of the narrow strip, which represents lowerat of the total area of the Republic to new communities (industrial - agricultural tourism) in addition to insufficient attention to rural development to reduce migration (From rural to urban). These cities did not absorb the increase and the weakness of facilities, which eventually led to an increase in the number of displaced persons to urban cities. This resulted in an increase in building rates in the outskirts of these cities or an increase in the number of floors of buildings.

H-Inadequate income: The imbalance of incomes of many individuals in Egyptian society, with rising prices globally and locally, as well as the existence of a percentage of 
unemployment, which led to the use of informal housing as appropriate as possible, in addition to an Absence of localities and officials responsible for the land:

I-The main responsibility lies in the spread and growth of slums, in localities and specialized agencies, where these devices are slow, in addition to the weakness of their performance for building violations and the random extension of the state lands and agricultural lands.

J-Consequently, of good quality housing has continued to go on for decades. The multiplicity of these responsible and competent authorities has led to widespread responsibility and negligence in implementing the conditions of demolition and noncompliance with urban planning.

With the above reasons. It is difficult to quantify all the causes and factors that led to the emergence or growth of informal settlements or indirectly contributed to their growth and spread, but it is clear that the process of growth of informal settlements is the result of several factors or conditions that may be global, regional or local factors, emphasizing the economic, social and cultural factors that led to informal growth.

\subsection{Reasons for the graveyard housing}

\section{2-2-1 Compelling reasons: among them:}

A-The demolition of old houses in the popular neighborhoods, the construction of buildings in their place, which led to the migration of poor segments of the population and their direction to the cemetery.

B-The deterioration of buildings in the old neighborhoods, the collapse of many of them as a result of the high level of water leakage, especially sewage, and this led to a massive movement to the area of the cemetery, both to the residential islands or squares

C-Administrative eviction and expropriation that accompanied many urban projects such as the construction of main roads, and the poor people did not find a substitute for the use of cemeteries for shelter.

2-2-2. Reasons for this huge displacement to the graves:

A- The completion of services for the inhabitants of settlement, their economic and urban structures became small towns within the confines of graveyards, schools, police stations, markets and craft activities.

B-The intervention of the state directly in the establishment of political organizations that took their headquarters within the old homes of the former aristocratic families, and the conversion of some of the administrative - building to schools such as Prince Ahmed Kamal, and to health clinics such as Naseem Pasha Square at Imam Shafei.

C-To end the isolation of the cemeteries and to include them more and more in the rapid urban road network, following the construction of Selah Salem road and then the highway at a later time.

D- Operating the main public transport lines so as to serve the inhabitants of populated islands, the number of lines in the area of Imam Al-Shafi'I reached more than 15 lines, in addition to the establishment of final parking spaces for public transport buses in Imam Al-Shafi'i Mosque, Nafisa, Barqouq mosque and Ain Al-Sira.

E- Providing some of these areas with public utilities, sewage water network, electricity and television, as well as the provision of social and administrative services.

F- Ignoring many abuses, through the staff of the cemeteries and education who exploit the empty land, inside the cemeteries, by laying the hand and building the multi-floor residential buildings on them, then leasing or making an ownership of the new displaced people.

3-The salient features of informal-random-and graveyards housing: They are summarized in this study as the most important characteristics of the housing of graveyard and informal according to the following figure: 

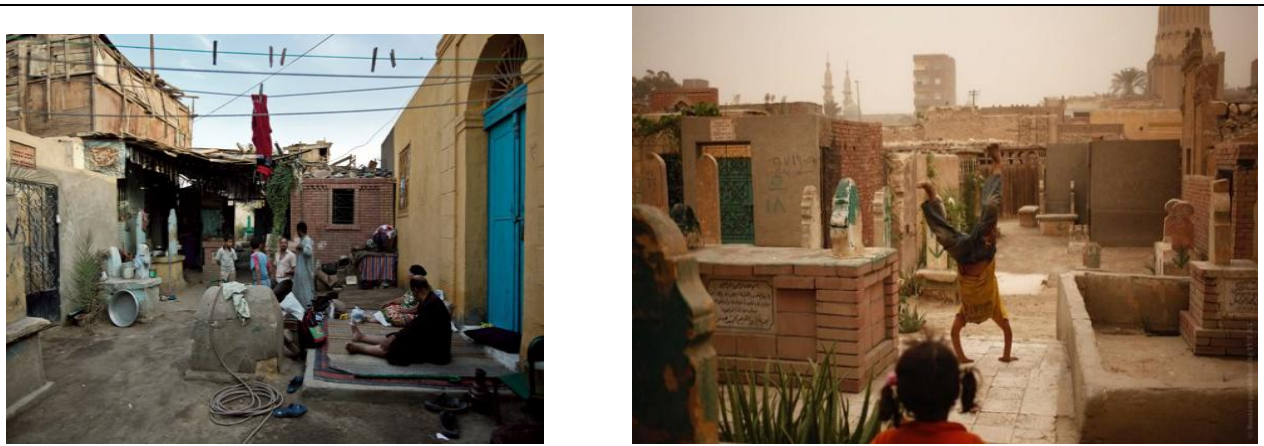

some services (nursery-school) inside the graves areas.

\section{The most important features that characterize graveyard and informal housing .}

\begin{tabular}{|c|c|c|}
\hline Graveyard housing & Informal -random-housing & For comparison \\
\hline $\begin{array}{l}\text { - Most of Cairo's graves are } \\
\text { well planned, with wide, } \\
\text { straight streets interspersed } \\
\text { with large spaces }\end{array}$ & $\begin{array}{l}\text {-The appearance of } \\
\text { underdevelopment has } \\
\text { prevailed in most informal- } \\
\text { random-housing, which are } \\
\text { evident from the shape of its } \\
\text { winding streets where they } \\
\text { were set up without planning. }\end{array}$ & $\begin{array}{l}\text { A-Environmental building } \\
\text { characteristics } \\
\text { 1-General features of } \\
\text { buildings and roads. } \\
\text { 2-- Planning pattern }\end{array}$ \\
\hline $\begin{array}{l}\text { - This type is simple. } \\
\text { - There is no place where the } \\
\text { construction is above the } \\
\text { graves. }\end{array}$ & $\begin{array}{l}\text { - This pattern is widely spread } \\
\text { and is either a retaining wall } \\
\text { or structural. }\end{array}$ & $\begin{array}{l}\text { 3. Housing patterns } \\
\text { - Style of multi-floor buildings } \\
\text {--Style of buildings with } \\
\text { internal graveyards }\end{array}$ \\
\hline $\begin{array}{l}\text { This type is very widespread } \\
\text { and this room is the tomb of } \\
\text { the cemetery. }\end{array}$ & $\begin{array}{l}\text { - There is this type to conduct } \\
\text { household activities inside. } \\
\text {-This type spreads as it offers } \\
\text { shelter for new residents and } \\
\text { all activities are implemented } \\
\text { in a single room. }\end{array}$ & -Residential room style \\
\hline $\begin{array}{l}\text {-There is no aesthetic picture } \\
\text { due to the monstrous view of } \\
\text { the tombs }\end{array}$ & $\begin{array}{l}\text {-lacks aesthetics sides due to } \\
\text { the adhesion of buildings. }\end{array}$ & $-4 \mathrm{Ae}$ \\
\hline $\begin{array}{l}\text {-It lacks any environmental } \\
\text { aspect. }\end{array}$ & $\begin{array}{l}\text { - It lacks gardens, green } \\
\text { spaces and a breather. }\end{array}$ & 5. Envir \\
\hline $\begin{array}{l}\text {-The facilities are derived } \\
\text { from the special facilities of } \\
\text { the graveyards so they are } \\
\text { informal-random- }\end{array}$ & $\begin{array}{l}\text {-Most areas are characterized } \\
\text { by the lack of facilities } \\
\text { (electricity, wastewater). }\end{array}$ & 6.1 \\
\hline $\begin{array}{l}\text {-Due to the severity of poverty } \\
\text { and the scarcity of schools. } \\
\text { - not overcome them. }\end{array}$ & $\begin{array}{l}\text {-Due to population rise, } \\
\text { extreme poverty and low } \\
\text { number of schools. }\end{array}$ & $\begin{array}{l}\text { B. Social and economic } \\
\text { characteristics } \\
\text { 1. Low level of education and } \\
\text { high illiteracy }\end{array}$ \\
\hline $\begin{array}{l}\text { - Few activities and they are } \\
\text { overlapped. }\end{array}$ & $\begin{array}{l}\text {-The majority of the rural } \\
\text { population is hay rate of the } \\
\text { population }\end{array}$ & $\begin{array}{lrr}\text { The } & \text { rural } & \text { origin } \\
\text { predominates } & \text { over } & \text { the } \\
\text { population } & & \\
\end{array}$ \\
\hline -vary from place to place. & $\begin{array}{l}\text {-The overlap of activities with } \\
\text { the absence of markets for } \\
\text { distribution, which leads to } \\
\text { offering them in streets } \\
\text {-Sometimes, it reaches double } \\
\text { percentage in normal areas. }\end{array}$ & $\begin{array}{l}\text { 3. Interference of activities } \\
\text { Increase population density }\end{array}$ \\
\hline $\begin{array}{l}\text {-There is no image of any } \\
\text { services views. }\end{array}$ & $\begin{array}{l}\text {-characterized by a severe } \\
\text { shortage of health services }\end{array}$ & 4. Poor health \\
\hline
\end{tabular}


4-General problems for informal and graveyard housing:

There have been several problems for each type according to the following table:

Types of problems for informal and graveyard housing

\begin{tabular}{|c|c|c|}
\hline Graveyard housing & Informal-random- housing & General problems \\
\hline $\begin{array}{l}\text { The spread of labor with } \\
\text { low productivity and poor } \\
\text { returns } \\
\text { 2. Increased pressure on } \\
\text { the network of facilities, } \\
\text { services and infrastructure } \\
\text { 3. High unemployment } \\
\text { rates } \\
\text { 4. Waste of human energies }\end{array}$ & $\begin{array}{l}\text {-Shrinking of agricultural land } \\
\text {-The spread of labor with low } \\
\text { productivity and poor returns } \\
\text { - Increase the pressure on the } \\
\text { network of facilities, services and } \\
\text { infrastructure } \\
\text { = High unemployment rates } \\
\text {-Loss of human energies }\end{array}$ & 1-Economic problems \\
\hline $\begin{array}{l}\text { 1. Weak social entity } \\
\text { 2. The prevalence of } \\
\text { negative values and habits } \\
\text { 3. Lack of youth centers, } \\
\text { cultural palaces or schools, } \\
\text { which leads young people } \\
\text { to deviate } \\
\text { 4. The spread of poverty } \\
\text { 5. Increase in child labor as } \\
\text { a result of illiteracy }\end{array}$ & $\begin{array}{l}\text { 1. Weak social entity } \\
\text { 2. The prevalence of negative } \\
\text { values and habits } \\
\text { 3. Lack of youth centers, cultural } \\
\text { palaces or schools, which lead } \\
\text { young people to be deviated. } \\
\text { 4. Spread of poverty } \\
\text { 5. An increase in child labor as a } \\
\text { result of illiteracy }\end{array}$ & 2-Social problems \\
\hline $\begin{array}{l}\text { 1-. Lack of any health care } \\
\text { 2. Multiple diseases and } \\
\text { epidemics }\end{array}$ & $\begin{array}{l}\text { 1.. Lack of health units } \\
\text { 2. Low health status of women } \\
\text { due to frequent reproduction, } \\
\text { early marriage and lack of health } \\
\text { care } \\
\text { 3. Frequent diseases and } \\
\text { epidemics of lack of health } \\
\text { awareness }\end{array}$ & 3-- Health problems \\
\hline \multirow[t]{2}{*}{$\begin{array}{l}\text { 1-Not equipped for } \\
\text { accommodation and } \\
\text { accommodation, are the } \\
\text { first and finally tombs } \\
2 . \text { Do not suffer from } \\
\text { narrow streets, but } \\
\text { characterized by width and } \\
\text { are straight }\end{array}$} & $\begin{array}{l}\text { 1. Not suitable for residence in } \\
\text { the absence of basic services and } \\
\text { facilities } \\
\text { 2. Narrow inner streets } \\
\text { 3. Different architectural style } \\
\text { from the prevailing pattern } \\
\text { around it. }\end{array}$ & 4-Urban problems \\
\hline & $\begin{array}{l}\text { Its existence is within urban areas } \\
\text { has led to increased } \\
\text { environmental pollution. }\end{array}$ & $\begin{array}{l}\text { 5- Environmental } \\
\text { problems }\end{array}$ \\
\hline
\end{tabular}




\section{Part 2: Applied study -Study Area:}

The selection of the northern graveyards located east of the city of Cairo is the practical study of the research:

\section{1-Location:}

The northern graveyard: The tombs of Al-Khafir are adjacent to the south and include several archaeological buildings: Dome and Khanqa, Sultan Al Ashraf School, Ain Qirqmash Mosque, Younis Dweidar Dome, Al-Nasser Faraj Bin Barqouq Mosque, Qabta Barsbay, Prince Suleiman.

2- Reasons for selecting the area of Diraya for the study area:

A-Reasons for choosing the area.

The region is unique in that it includes a large collection of the most important Mamluk Islamic monuments dating back more than five centuries ago. However, most of these buildings suffer from the decline in the external environment, handicrafts, etc. It is therefore important to eliminate all these infringements and to preserve these buildings and to improve the urban environment around them, in order to highlight these archaeological buildings and employ them within the integrated tourism system for urban upgrading in the region.

B: Special reasons in the functional nature of the study area:

1 - the arrival of many graves of the region to the maximum capacity.

2 - The spread of the islands on the vacant areas that used to separate the cemeteries in the past.

3 - the spread of the phenomenon of residential graves in most study area, especially the graves of Qaitbay and Qarafa neighbors

4- The spread of many craft and commercial activities in the region.

Thus making the area a focal point for urban and environmental pollution.

\section{3-Urban studies for the study area:}

A- Building Conditions: Old buildings, mostly poor and deteriorated, including medium and good, and modern buildings mostly good condition.

B- - Construction materials: Construction materials vary from: brick, and metal (Corogated) ceiling, and retaining walls in the old buildings and structural in modern buildings.

C- 3 - Height of buildings: Altitudes in the old buildings between the floors of two and three and the third floor is often added, while the modern buildings, ranging between three and six floors.

D- 4 - land uses: the predominant use of housing, followed by commercial and there are some workshops, there is a vegetable market area and some government services activities.

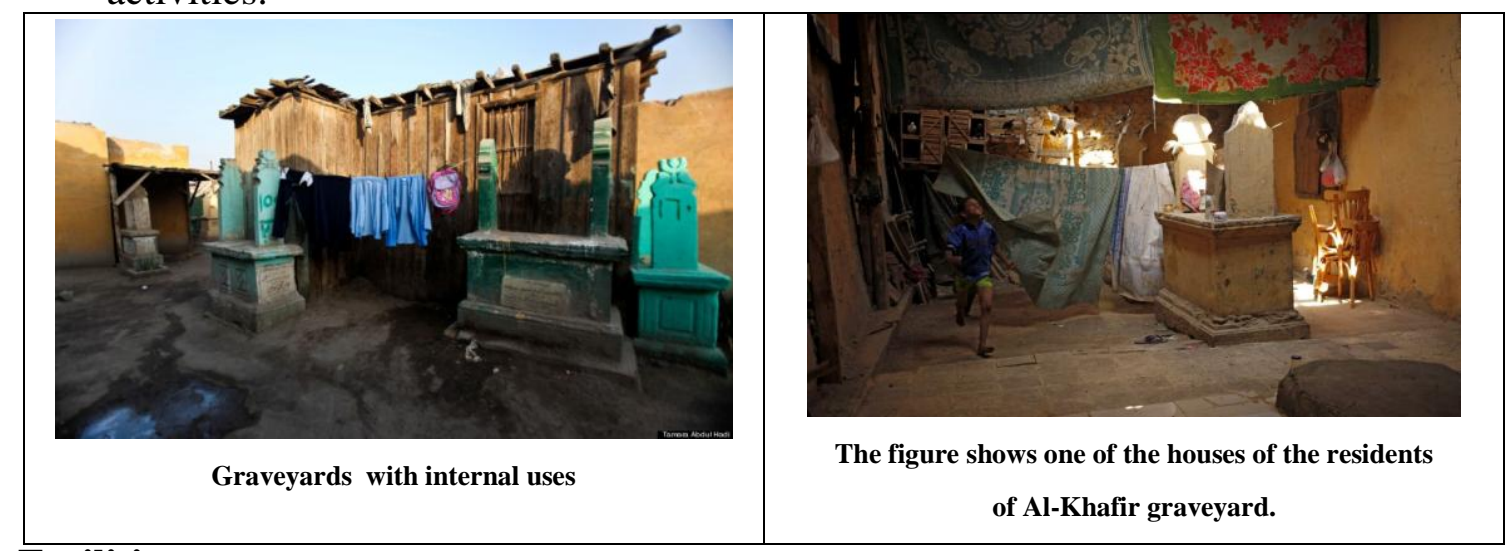

4. Facilities:

A-Water: Entered into all houses and in the old houses there is a tap for the whole building, because it cannot bear the entry of pipes to the entire building.

Electricity: The entire area is powered by electricity.

B-Sewage: The area is serviced by a sewerage system although some houses use a ground tank. 
C-Garbage: There is no garbage collection system, although there are boxes in more than one area around the area, but collection periods are spaced, leading to collection containers becoming a source of pollution to the environment.

D-Roads: The inner roads are 1 to 2 meters long, and a road between buildings with a width of 5 meters may be paved in some areas near the new axis.

The inner roads are sandy with width between 1-2

Electricity access to old and modern homes as well as telephone line

\section{Conclusions and Recommendations:}

The problem of slums in Egypt is one of the most important current problems, whose solution depends on several axes, including the economic axis, the architectural axis, the legal axis, etc. I have listed some of the proposed solutions to this problem from some aspects as a conclusion to this study.

- Increase the awareness throw media of the importance of solving this problem in effective ways.

- The establishment of modern laws for the possibility of transferring tombs outside the cities to reduce overcrowding and reuse their lands in making residential complexes for the people already live in it.

- The establishment of modern laws to reduce the area of the existing graves (which cannot be transferred outside the cities) and return to the legal burial system that uses smaller area and reuse of the available spaces in the construction of residential complexes for the people already live in it.

- Facilitate small loans for low-income people to facilitate owing suitable housing units and facilitate payment methods.

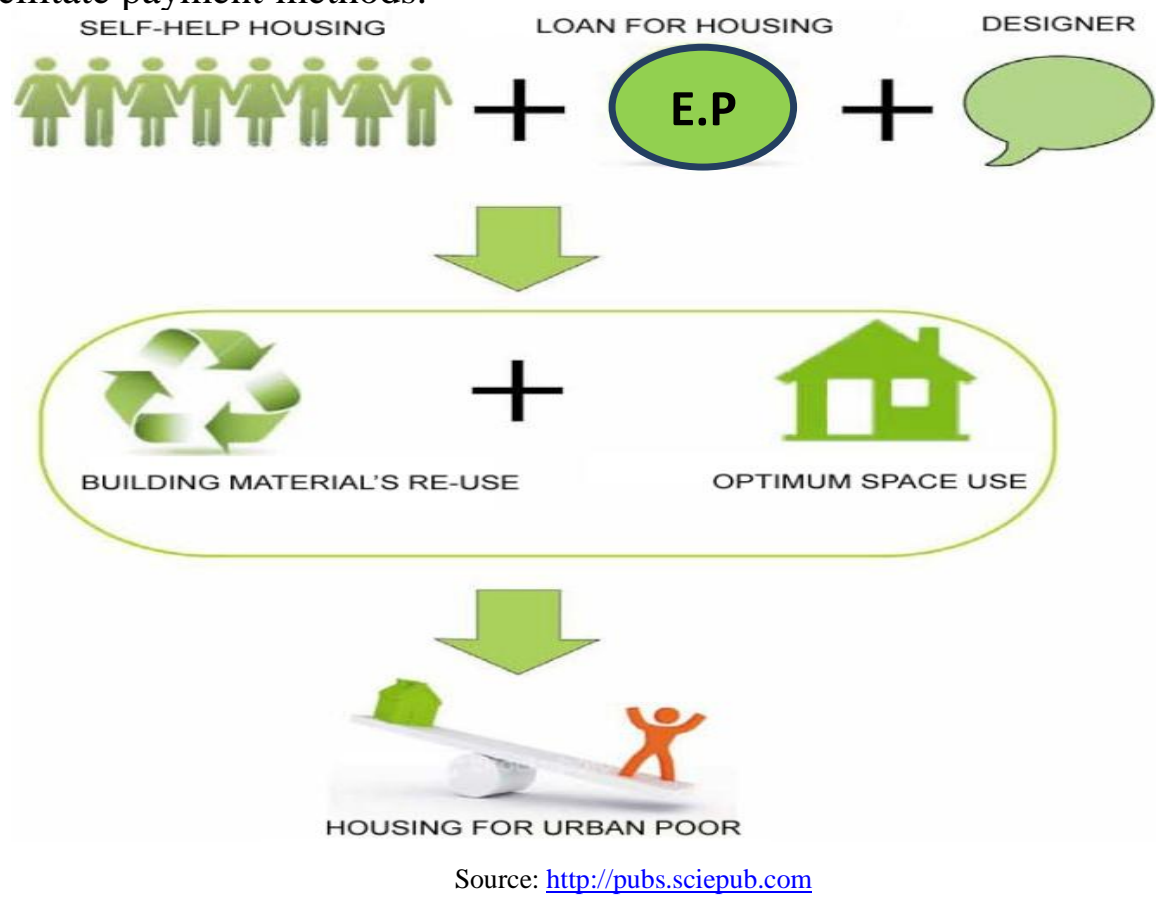

- Amend land ownership laws, facilitate access to desert lands by youth people, and support projects there to encourage migration to desert to reduce pressure on capitals.

- Provide jobs opportunities for young people to raise the level of their income, which makes it easier for them to obtain housing units in better areas.

- The work on a detailed social study for families living in slums and cemeteries and trying to solve their problems from its roots.

- Solve the problem of housing by design with the help of architects to replace the shabby and dilapidated buildings with suitable small size housing units with all possible living facilities.

- Expansion of the vertical construction instead of horizontal construction to save more lands to make more residential units and to make areas for social activities and gardens.

- Use of removable light buildings that could reused to reduce the price of residential units and make it easy to establish. 
- Non-formal - random - production .It is a response to the function, a shelter for living, and the small economic area, there is no interest in lighting or ventilation, the disproportion of the heights with the street view. Traditional production reflects habits, cultural traditions, environmental factors, model modification according to site conditions and environmental considerations.

- The informal output reflects the economic potential that is reflected in the small facades, and the relationship with the street network. The model is formed over the years. The traditional production depends on the culture of the society, respecting the environment and the location.

- The possibility of financing informal -random- production through the provision of land in installments as well as the process of construction (affordability) - Dependence on kinship and knowledge, which is a reason for the rapid growth of these communities, while traditional production is based on barter and equal economic potential, financing the construction process through the exchange on the basis of utility, There is no marketing of the structural product, leading to support of collective participation and exchange of craft and benefit.

- Supporting and helping NGOs and governmental organizations, as well as the private sector, in participating in the development and upgrading programs of degraded residential areas and improving living standards. In addition to work on restructuring the housing departments in the local units that manage and follow up the upgrading programs for degraded rehabilitation, which contributes to improving and improving the ability to understand the mechanisms of development and flexible and modern development.

- The axis has had the most impact on changing the ideas of the majority of the population. After the residents were afraid of being removed, leaving their homes after compensating the people whose homes were removed during the supply of the axis and giving them alternative apartments in the Barajil,

- These regions represent an element of self-effort for low-income individuals, indicating the ability and capacity of individuals to solve their problems without governmental assistance.

\section{REFERENCES}

1. Understanding Slums - The Challenge of Slums- UN Globule report on Human settlement - UN HABITAT - 2003.

$$
\begin{aligned}
& \text { 2. محاضر ات تمهيدي ماجستير - د. على محمد عبد الله الصاوي - در اسات معمارية ـ مادة العمارة الإقليمية و المحلية ـ } \\
& 2002 \text { - } 2001 \\
& \text { 3. غادة مجمد ريحان - عمليات الارتقاء بالمناطق العشوائية في فاعلية تنفيذ المخططات - رسالة ماجستير - قسم الهندسة }
\end{aligned}
$$

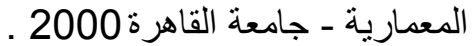

$$
\begin{aligned}
& \text { 4. عزة أمين سرى - المناطق الريفية المحتو اة فى العمر ان الحضري ـ دراسة تحليلية مقارنة ـ رسالة ماجستير - قسم }
\end{aligned}
$$

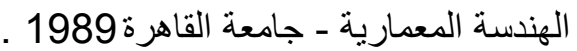

$$
\begin{aligned}
& \text { 5. عمرو محمد الظو اهري - التجمعات الريفية داخل المدن مع ذكر خاص للقاهرة الكمة الكبرى - رسالة ماجستير - قسم }
\end{aligned}
$$

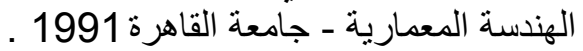

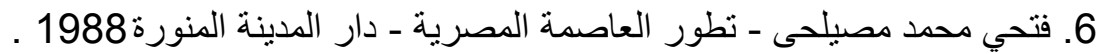

$$
\begin{aligned}
& 7 \text { ـ المجالس القومية المتخصصة، ( } 1999 \text { ( } 199 \text { )، الإسكان العشوائي الهامشي وإسكان المقابر، تقرير المجلس القوميللخدمات } \\
& \text { و التنمية الاجتماعية، الدورة العشرون - القاهرة . }
\end{aligned}
$$

